УДК 346.546

DOI https://doi.org/10.32849/2663-5313/2021.5.06

\title{
Валерій Полюхович,
}

докт. юрид. наук, старший науковий співробітник,

завідувач відділу правового забезпечення ринкової економіки

Науково-дослідного інституту приватного права і підприємництва

імені академіка Ф.Г. Бурчака Начіональної академї правових наук України

\section{НОВІ ЗАКОНОДАВЧІ ІНІЦАТИВИ З УДОСКОНАЛЕННЯ ЗАКОНОДАВСТВА ПРО ЗАХИСТ ЕКОНОМІЧНОЇ КОНКУРЕНЦІЇ}

У статті проаналізовано зміст проєкту закону України «Про внесення змін до деяких законодавчих актів щодо вдосконалення діяльності Антимонопольного комітету України» № 5431 від 27.04.2021 у частині запропонованих змін до Закону України «Про Антимонопольній комітет України» та Закону Украйни «Про захист економічної конкурениії».

Автор звернув увагу на непослідовність законодавия у справі нормативного вирішення давно назрілих проблем. Проте і запропоновані ініціативи загалом варті уваги та заслуговують на впрова дження після певного доопращювання.

Так, слушними є запропоновані новели до Закону України «Про Антимонопольній комітет України з удосконалення процедури, уточнення та деталізачії змісту повноважень органів АМКУ щодо перевірки з метою збирання доказів у вигляді інформащії, закріплення на рівні закону норми оплати прачі посадових осіб АМКУ.

Пропозииї щодо закріплення обов'язку звернення органів АМКУ до суду для надання дозволу на проведення перевірок, накладення арешту або вилучення документів та затвердження угоди про врегулювання справи мають неоднозначний характер з огляду на забезпечення збирання доказів по справі. Вважаємо, що проведення перевірок, накладення арешту або вилучення документів можуть здійснюватися з наступним отриманням погодження суду, а не з попереднім, бо інакше втрачається раптовість під час проведення перевірки, а відповідно, здебільшого і сенс ї̈ проведення.

Запропоновано положення про те, що органи Антимонопольного комітету України мають право не розпочинати розгляд справи за заявами суб'єктів господарювання, громадян, об'єднань, установ, організацій, поданнями органів державної влади, органів місиевого самоврядування, органів адміністративно-господарського управління та контролю, якщо зазначені в заяві ознаки порушення законодавства про захист економічної конкурениії не відповідають встановленим Антимонопольним комітетом України пріоритетам його діяльності є таким, що прямо суперечить нормам чинного законодавства Украйни, а тому є неприйнятним.

Об'єктивно доцільним є доповнення Закону України «Про захист економічної конкуренцї» статтею 44-1 «Проведення перевірки», статтею 46-1 «Врегулювання у справах про антиконкурентні узгоджені дії та зловживання монопольним (домінуючим) становищем», а також запровадження солідарної та субсидіарної відповідальності під час сплати накладеного органами Комітету штрафу.

Ключові слова: реформування системи правового регулювання, захист економічної конкурениіі, антимонопольне регулювання, програма ліненсі, солідарна та субсидіарна відповідальність.

Постановка проблеми. Як ми вже зазначали в попередніх публікаціях 3 питань нормативного забезпечення захисту економічної конкуренції в Україні, кадрові зміни вищих ешелонів державної влади України в результаті президентських та парламентських виборів 2019 р. стали «тригером» до так званого «турборежиму» законотворчих процесів, у тому числі і в означеній сфері господарських відносин. Проте жоден із цілої низки підготовлених об'ємних законопроєктів із питань антимонопольного регулювання не набув статусу нормативного акту, а лише одиниці дібралися до першого читання, після якого були успішно покладені на полицю до кращих часів. Таким чином, розпіарена конкуренційно-антимонопольна реформа повністю провалена і залишилася в нашій пам'яті як один із численних нереалізованих законотворчих проєктів. Але існуючі проблеми функціонування системи захисту економічної конкуренції нікуди не зникли і потребують свого вирішення.

Виклад основного матеріалу дослідження. У попередніх статтях з означеної тематики нами було проаналізовано зміст 
низки законопроектів, зокрема в частині можливих змін до Закону України «Про Антимонопольний комітет України», а саме щодо організаційних засад функціонування органів антимонопольного регулювання [1] та до Закону України «Про захист економічної конкуренції» щодо процесу забезпечення такого захисту [2].

Нові законодавчі ініціативи, що викладені в тексті проєкту закону України «Про внесення змін до деяких законодавчих актів щодо вдосконалення діяльності Антимонопольного комітету України» № 5431 від 27.04.2021 [3] (далі по тексту - законопроєкт № 5431 від 27.04.2021) також мають своїм предметом реформування вищезазначених законів України, проте вже дещо в інших нормативних аспектах немовби попередні законопроєкти були прийняті, а відповідно, проблеми, які вони були покликані вирішити, зникли. На жаль, це не так, проблеми залишилися там, де і були, та ще й зросли, а якість функціонування системи захисту економічної конкуренції знизилася, бо зростають вимоги суспільства до якості правового та організаційного забезпечення, а застарілий механізм державного регулювання менш якісно справляється з викликами часу.

Це стосується передусім питання кадрового забезпечення функціонування Антимонопольного комітету України. Як ми пам'ятаємо, неодноразово піднімалося питання, у тому числі й у межах попередніх законопроєктів із цієї тематики, про розмежування в діяльності державних уповноважених АМКУ їньої основної роботи за посадою і виконання функцій у межах процедури оскарження публічних закупівель. Були різні пропозиції, які ми детально аналізували в наших попередніх публікаціях, покликані оптимізувати процес розгляду скарг на процедури публічних закупівель. Пропонувалося збільшення кількості держаних уповноважених, зміну строку їх перебування на посаді, створення окремих посад уповноважених із розгляду скарг про порушення законодавства у сфері публічних закупівель, створення окремого органу оскарження у сфері публічних закупівель, створення спеціалізованого суду з питань захисту економічної конкуренції тощо. Ці пропозиції були різноплановими - від деталізованих із визначенням правового статусу уповноважених та особливостей процедури, створення нових органів до простих «як постріл» пропозицій щодо збільшення кількості державних уповноважених. Також у попередніх законопроєктах неодноразово та різнопланово пропонувалося внесення змін до існуючого порядку призначення вищих посадових осіб Антимонопольного комітету України голови, заступників та державних уповноважених. Проте, як уже сказано, усі ці ініціативи в результаті були покладені на полицю і жодна з них не реалізована.

У зв'язку із цим викликає подив той факт, що в межах нового законопроєкту № 5431 від 27.04.2021, який також підготовлений Комітетом Верховної Ради України з питань економічного розвитку, будь-які ініціативи із цих питань відсутні, а самих проблем ніби немає чи вони, як кажуть, залишилися в історії.

Загалом у законопроєкті № 5431 від 27.04.2021 в частині внесення змін до Закону України «Про Антимонопольний комітет України» [4] запропоновано низку новел 3 удосконалення процедури, уточнення та деталізації змісту повноважень органів АМКУ, закріплення на рівні закону норми оплати праці посадових осіб АМКУ. Проте за обсягом представленого нормативного матеріалу складається враження, що основною метою внесення змін саме до Закону України «Про Антимонопольний комітет України» є закріплення нових посадових окладів працівників АМКУ. Що ж про це можна сказати? Питання оплати праці є важливим, а сама оплата праці є значним стимулом у роботі окремого працівника. Проте, на нашу думку, просте збільшення розміру оплати праці без оптимізації організаційних засад функціонування органу є недостатнім для підвищення його ефективності та свідчить про відсутність у законодавця будь-яких ідей щодо оптимізації існуючих виробничих процесів, окрім ідеї за допомогою збільшення фінансування компенсувати працівникам надмірне перевантаження, що є наслідком серйозних дисбалансів в організації роботи органу. Це примітивний підхід до вирішення існуючих проблем. Коли більш раціонально було б спрямувати зусилля на ліквідацію існуючого дисбалансу шляхом оптимізації системи, а матеріальне заохочення використовувати в якості додаткового стимулу.

Проте стисло розглянемо запропоновані зміни до Закону України «Про Антимонопольний комітет України» відповідно по порядку їх викладення.

Так, пропонуються зміни, якими уточнюються та деталізуються повноваження Антимонопольного комітету України, державного уповноваженого АМКУ, голови територіального відділення АМКУ щодо проведення перевірки з метою збирання доказів у вигляді інформації. Зміни корисні та відповідають вимогам часу. Проте, на нашу думку, не менш важливим повинно бути вдосконалення засобів для забезпечення збирання доказів. Сьогодні серед повноважень органів 
АМКУ передбачено можливість залучення поліцейських, працівників митних та інших правоохоронних органів для забезпечення проведення розгляду справи про порушення законодавства про захист економічної конкуренції, зокрема в разі проведення розслідування. Проте на практиці ця норма не працює, бо відсутні нормативно закріплені процедурні механізми такого залучення, у тому числі в законодавчих актах, якими регулюється діяльність поліцейських, працівників митних та інших правоохоронних органів. Тому необхідно саме у цій частині нормативне закріплення обов'язку відповідних силових структур реагувати на звернення органів АМКУ для забезпечення проведення розслідування із залученням силових підрозділів. Адже у АМКУ відсутні власні силові підрозділи, що ми вважаємо суттєвим недоліком у справі забезпечення розслідування та збирання доказів.

Також пропонується внесення змін до ст. 23-1 Закону, якими уточнюються процедурні особливості проведення слухань у справах про надання дозволу на узгоджені дії, концентрацію, про порушення законодавства про захист економічної конкуренції в частині порядку призначення слухань, їх технічної фіксації, наступного протоколювання і порядку ознайомлення. Раніше подібні норми були закріплені у відомчих актах АМКУ, а підвищення рівня їх закріплення до рівня Закону України об'єктивно доцільне.

Пропозиції до статті 25 Закону, що закріплюють обов'язок звернення органів АМКУ до суду для надання дозволу на проведення перевірок, накладення арешту або вилучення документів та затвердження угоди про врегулювання справи, мають неоднозначний характер $з$ огляду на необхідність забезпечення збирання доказів по справі. Із можливістю затвердження судом угоди про врегулювання справи у цілому можна погодитися, бо залучення суду як інстанції, яка контролює дотримання законності, є цілком можливим, хоча в такому разі доцільним було б, щоб така угода набувала чинності з моменту іï укладення, а не 3 моменту іï затвердження судом, бо саме затвердження може бути затриманим у часі, що завдасть шкоди інтересам сторін угоди. Незатвердження судом такої угоди означатиме втрату iï чинності з моменту укладення. Водночас питання отримання органами АМКУ попереднього дозволу суду на проведення перевірок є таким, що напряму шкодить діяльності органів АМКУ щодо виявлення правопорушень та збирання доказів. У практиці конкурентних органів багатьох країн світу є так звані «рейди на світанку», що є засобом раптової перевірки, що знижує можливість потенційного порушника приховати документальні докази протиправної діяльності. Тому вважаємо, що проведення перевірок, накладення арешту або вилучення документів може здійснюватися із наступним отриманням погодження суду, а не 3 попереднім, бо інакше втрачається раптовість під час проведення перевірки i, відповідно, здебільшого і сенс іï проведення.

До ст. 27 Закону пропонується внесення змін, відповідно до яких визначаються чіткі розміри заробітної плати посадових осіб Антимонопольного комітету України у їх безпосередній прив'язці до розміру прожиткового мінімуму. Сьогодні діє порядок прив'язки посадових окладів до окладів визначених для відповідних посад органів виконавчої влади, а державних службовців - відповідно до Закону України «Про державну службу». Запропоновані зміни спрямовані на нормативне відокремлення АМКУ у сфері оплати праці від інших державних органів. Але, як нами зазначено вище, збільшення рівня оплати праці є хорошим стимулом для посадових осіб, але без інших системних змін є недостатнім для підвищення якості їх функціонування.

Значний обсяг змін запропоновано для внесення до Закону України «Про захист економічної конкуренції» [5]. Запропоновані новели мають суттєвий характер та в певних межах відображають назріли зміни, але поряд із тим в окремих частинах є неоднозначними та потребують додаткової аргументації. Звернемо увагу на найбільш суттєві, на нашу думку, пропозиції.

Пропонується уточнити визначення поняття «контроль» шляхом визначення можливості як кваліфікуючої ознаки вирішального впливу на господарську діяльність. Погоджуємося з доцільністю цієї пропозиції.

Також запропоновано внесення змін до статей 22, 24 Закону, що уточнюють вимоги до отримання дозволу АМКУ на концентрацію суб'єктів господарювання. Загалом має місце уточнення порядку визначення вартісних показників учасників концентрації, а самі вартісні показники у цілому залишаються в існуючих межах.

Також передбачено можливість подовження строку розгляду справи про узгоджені дії чи концентрацію на один місяць поряд 3 існуючим тримісячним строком, якщо учасники концентрації нададуть пропозиції щодо прийнятих на себе зобов'язань під час здійснення ними концентрації чи узгоджених дій.

Запропоновано також суттеве підвищення плати із заяв про надання дозволу на 
концентрацію з 1200 до 2500 неоподатковуваних мінімумів доходів громадян (НМДГ), із заяв про надання дозволу на узгоджені дії із 600 до 1500 НМДГ. Відповідно, підвищено й плату за надання попередніх висновків з означених питань та з висновків відповідно до статей 14, 29 Закону.

Ці зміни логічні та давно назріли і зумовлені вимогами часу. Водночас зміни, запропоновані до ст. 36 Закону шляхом доповнення іï частиною третьою, викликають подив та потребують окремого коментаря. У зв'язку із цим варто навести запропоновану редакцію ч. 3 ст. 36 Закону повністю:

«3. Органи Антимонопольного комітету Украӥни мають право не розпочинати розгляд справи за заявами суб'єктів господарювання, громадян, об'єднань, установ, організаиій, поданнями органів державної влади, органів місцевого самоврядування, органів адміністративно-господарського управління та контролю, якщо зазначені в заяві ознаки порушення законодавства про захист економічної конкурениії не відповідають встановленим Антимонопольним комітетом України пріоритетам його діяльності.

Про відмову в розгляді справи, яка не відповідає встановленим пріоритетам діяльності Антимонопольного комітету Украйни, Антимонопольний комітет України, адміністративна колегія територіального відділення Антимонопольного комітету України приймають мотивоване розпорядження.»

По суті, запропоновані зміни дають змогу Антимонопольному комітету не розслідувати зловживання монополістів та картелей, які не відповідають пріоритетам діяльності відомства, узаконюючи принцип вибірковості під час застосування норм права Більше того, у законодавстві відсутні норми, якими б визначалися «пріоритети» діяльності АМКУ та відповідності цих пріоритетів чинному законодавству України, зокрема нормам Конституції України та Закону України «Про Антимонопольній комітет України», Закону України «Про захист економічної конкуренції». За аналогією можна вести мову про внесення змін до кримінального законодавства і дозволу правоохоронним органами виносити мотивоване розпорядження про відмову в розслідуванні злочину, який вони не вважають пріоритетним. При цьому йдеться не про декриміналізацію певних складів правопорушень, що є легітимним шляхом розвитку законодавства, а про «особливий» шлях звільнення правопорушників від відповідальності. Безумовно, можливе запровадження такої норми буде прямим порушенням як принципів, так норм Конституції України та законів України.
Щодо пропозицій до ст. 37 Закону по доповнення її частиною 4 і визначення права органу АМКУ не направляти суб'єкту господарювання повідомлення про початок розгляду справи до проведення його перевірки, то вони цілком слушні і заслуговують на прийняття, бо мають на меті отримання доступу до інформації, яка може містити докази протиправної діяльності, яка в іншому разі може бути втрачена для органів АМКУ.

Доповнення Закону України «Про захист економічної конкуренції» статтею 44-1 Проведення перевірки виправдано лише доцільністю підвищення рівня правового регулювання здійснення цих процедур, що сьогодні врегульовуються відповідним положенням АМКУ, яке зареєстроване в Міністерстві юстиції України.

Водночас доповнення закону статтею 46-1 «Врегулювання у справах про антиконкурентні узгоджені дії та зловживання монопольним (домінуючим) становищем» потребує окремого коментаря з огляду на їі зміст. Так, передбачено, що процедура врегулювання у справі може бути розпочата після направлення попередніх висновків у справі про порушення законодавства про захист економічної конкуренції та до прийняття рішення у справі органом Антимонопольного комітету України. Відповідач після отримання попередніх висновків у справі може подати клопотання до відповідного органу Антимонопольного комітету України про врегулювання справи. Урегулювання здійснюється шляхом підписання угоди про врегулювання справи між відповідним органом Антимонопольного комітету України та відповідачем, яка затверджується господарським судом.

У цій частині процедура не викликає зауважень. Проте передбачено, що істотними умовами угоди про врегулювання справи є:

- визнання відповідачем факту вчинення порушення, зазначеного в попередніх висновках;

- визнання відповідачем розміру штрафу;

- зменшення розміру штрафу на 15\%, який мав бути накладений у разі незастосування процедури врегулювання органом Антимонопольного комітету України.

У зв'язку із зазначеним незрозуміло, чим зумовлена саме 15-відсоткова знижка розміру штрафу. До того ж незрозуміло, чи позбавляє відповідача факт укладення такої угоди 3 наступним затвердженням їі господарським судом права на подальше оскарження такого рішення відповідачем у майбутньому. На нашу думку, ця норма виглядає достатньо сирою і потребує деталізації та доопрацювання. 
Пропонується доповнити ст. 50 Закону пп. 21, 22 двома новими складами правопорушень щодо неявки представників суб'єктів господарювання на виклик органів АМКУ для надання пояснень та самочинне розпломбування (розпечатування) приміщень, опломбованих посадовими особами органів АМКУ, здійснення яких карається штрафами у розмірі до одного відсотка від доходу суб'єкта господарювання за останній звітний рік. На нашу думку, запропоноване положення п. 21 потребує уточнення про те, що застосування штрафних санкцій можливе за умови відсутності поважних причин для неявки представників суб'єктів господарювання на виклик органів АМКУ, що особливо $\epsilon$ актуальним в умовах карантинних заходів.

Запропоновано в ст. 6 Закону виключити положення, що передбачали можливість застосування так званої програми ліненсі, яка передбачає, що якщо учасник картелю звертається до органів АМКУ із заявою про участь у ньому раніше за інших учасників та надає суттєву інформацію, то він звільняється від відповідальності за ст. 52 Закону. Натомість запропоновано доповнити Закон ст. 52-1 «Підстави та порядок звільнення від відповідальності учасників антиконкурентних узгоджених дій». Процедура звільнення від відповідальності більш деталізована, визначено цілий перелік підстав, які в сукупності будуть підставою для повного звільнення від відповідальності за вчинення антиконкурентних узгоджених дій, передбачених ст. 52 цього Закону. Для інших заявників, які не можуть бути повністю звільнені від відповідальності, передбачено пропорційне зменшення розміру від попередньо розрахованого розміру штрафу залежно від черговості звернення: перший заявник - до 50\%, другий заявник до $30 \%$, інші заявники - до 20\%. Також передбачено суворі обмеження щодо звільнення від відповідальності та не менш суворі обов'язки особи, що співпрацює з органами АМКУ.

Після ознайомлення із запропонованими новелами складається враження, що потенційні учасники картелів та, відповідно, порушники конкурентного законодавства навипередки біжать до органів АМКУ з метою прибігти першими та щонайбільше надати інформації про своїх колег та партнерів по узгодженим діям, які мають ознаки антиконкурентних, а вже потім напружено чекають, до якої черги вони потраплять для зменшення можливого штрафу. Усе це виглядає достатньо дивно 3 огляду на існуючу практику застосування так званої «програми ліненсі» в минулому, адже реально ця програма не працює. Наша бізнес-спільнота загалом не сприймає явку з повинною як модель пове- дінки. Можливо, це пов'язано з тим, що завтра доведеться працювати з тими самими партнерами, на яких ти сьогодні доніс, щоб виторгувати собі звільнення від відповідальності. 3 мого особистого досвіду роботи на посаді державного уповноваженого можу зазначити, що в роботі органів АМКУ були спроби прихованого залучення учасників картельних змов до співпраці на умовах програми ліненсі, але в результаті і по відношенню до таких учасників потім застосовувалися санкції, що, звичайно, серйозно підірвало їхню довіру до можливості співпраці у такій формі з органами АМКУ. Справа в тому, що зазначений у п. 5 ст. 6 Закону механізм програми ліненсі не співвідноситься 3 механізмом прийняття рішень АМКУ щодо накладення санкцій, адже під час прийняття рішень відбувається голосування державних уповноважених чи членів адміністративної колегії по конкретній справі, а тому, відповідно, про наявність учасника картельної змови, який пішов на співпрацю з органами АМКУ, повинно бути відомо всім членам колегіального органу, повинен існувати відповідний документ, що підтверджуе факт співпраці та підставу для звільнення від відповідальності, та й саме звільнення від відповідальності стане відомим усім учасникам процесу у відкритому засіданні органу АМКУ . Тобто зберегти факт співпраці в таємниці від інших учасників картельної змови фактично неможливо, а отже, і сам механізм для потенційного учасника програми ліненсі стає менш привабливим. Тому на практиці застосування норми п. 5 ст. 6 Закону не знайшло свого реального втілення. Наведені законодавчі пропозиції в ст. 52-1 встановлюють достатньо жорсткий порядок застосування звільнення від відповідальності та, з огляду на існуючий досвід застосування програми ліненсі, навряд чи будуть широко використовуватися в практичному застосуванні.

Також достойними уваги новелами є запровадження солідарної (п. 4 ст. 52 Закону) та субсидіарної (п. 11 ст. 56 Закону) форм відповідальності під час сплати штрафів, накладених органами АМКУ.

Так, у п. 4 ст. 52 Закону запропоновано, що у разі коли декілька юридичних та/або фізичних осіб - суб'єктів господарювання, які входять до групи, що визнається суб'єктом господарювання, вчинили діяння (дії, бездіяльність), які призвели до порушення законодавства про захист економічної конкуренції зазначеним суб'єктом господарювання, штраф накладається на суб'єкт господарювання в особі цих юридичних та/або фізичних осіб та/або на юридичних та/або фізичних осіб - суб'єктів господарювання, які мають вирішальний вплив на діяльність цих 
юридичних та/або фізичних осіб у межах групи. Обов'язок сплати штрафу, накладеного на цих юридичних та/або фізичних осіб суб'єктів господарювання, є солідарним.

А в п. 11 ст. 56 Закону пропонується визначити, що у разі якщо стягнення з особи накладеного органами Антимонопольного комітету України штрафу $є$ неможливим унаслідок припинення такої особи, доведення до банкрутства або недостатності майна в результаті дій його засновників (учасників, акціонерів), які мають право давати обов'язкові для відповідача вказівки, правонаступники відповідача, засновники (учасники, акціонери), що входять до групи, яка визнається суб'єктом господарювання відповідно до ст. 1 цього Закону і до якої на момент вчинення правопорушення входила особа, на яку органами Комітету було накладено штраф, солідарно несуть субсидіарну відповідальність щодо сплати накладеного органами Комітету штрафу.

Ці новели є позитивним кроком для забезпечення реального стягнення накладених штрафів, проте їх практичне застосування вимагає суворого дотримання базових норм статей 541, 542, 543, 619 ЦК України та наявності належної доказової бази, що б унеможливлювало б вільне трактування норм Закону для притягнення, по суті, третіх осіб до відповідальності за формальними ознаками без належних реальних підстав.

\section{Висновки}

У цілому представлений проєкт закону України «Про внесення змін до деяких законодавчих актів щодо вдосконалення діяльності Антимонопольного комітету України» № 5431 від 27.04.2021 містить достатньо багато корисних новел у сфері правового забезпечення захисту економічної конкуренції, хоча й залишає поза увагою низку існуючих проблем та прогалин у цій сфері правового регулювання.

\section{Список використаних джерел:}

1. Полюхович В. Перспективи вдосконалення законодавства про захист економічної конкуренції (з практики законотворення). Підприємництво, господарство і право. 2020. № 10. С. 51-60.

2. Полюхович В. Щодо окремих законодавчих пропозицій до Закону України «Про захист економічної конкуренції». Підприємниитво, господарство і право. 2020. № 12. С. 75-79.

3. Проєкт закону України «Про внесення змін до деяких законодавчих актів щодо вдосконалення діяльності Антимонопольного комітету України» № 5431 від 27.04.2021. Офіиійний вебпортал Верховної Ради України. URL: http://w1.c1.rada.gov.ua/ pls/zweb2/webproc4 1?pf3511=71771.

4. Закон України «Про Антимонопольний комітет України» від 26 листопада 1993 р. № 3659-XII. Відомості Верховної Ради України (BВP). 1993. № 50. Ст. 472.

5. Закон України «Про захист економічної конкуренції». Відомості Верховної Ради України (BBP). 2001. № 12. Ст. 64.

Valeriy Polyukhovych. New legislative initiatives to improve legislation on protection of economic competition

The article analyzes the content of the draft Law of Ukraine "On Amendments to Certain Legislative Acts to Improve the Activities of the Antimonopoly Committee of Ukraine" № 5431 of 27.04.2021 in terms of proposed amendments to the Law of Ukraine "On the Antimonopoly Committee of Ukraine" and the Law of Ukraine "On Economic Protection competition ".

The author drew attention to the inconsistency of the legislator in the matter of normative solution of long overdue problems. However, the proposed initiatives are noteworthy and deserve to be implemented after some refinement.

Thus, the proposed amendments to the Law of Ukraine "On the Antimonopoly Committee of Ukraine" to improve the procedure, clarify and detail the content of the powers of the AMCU to inspect in order to gather evidence in the form of information, enshrine in law the remuneration of officials of the AMCU.

Proposals to establish the obligation of the AMCU to apply to the court for permission to conduct inspections, seize or seize documents and approve a settlement agreement are ambiguous in view of ensuring the collection of evidence in the case. We believe that inspections, seizures or seizures of documents may be carried out with the subsequent approval of the court, and not with the previous one. Because otherwise the suddenness of the inspection is lost, and accordingly, in many cases, the meaning of its conduct.

The proposed provision that the bodies of the Antimonopoly Committee of Ukraine have the right not to initiate proceedings on applications of business entities, citizens, associations, institutions, organizations, submissions of public authorities, local governments, administrative and economic management and control, if the signs of violation of the legislation on protection of economic competition specified in the application do not correspond to the priorities of its activity established by the Antimonopoly Committee of Ukraine is such that directly contradicts norms of the current legislation of Ukraine, and therefore is unacceptable.

It is objectively expedient to supplement the Law of Ukraine "On Protection of Economic Competition" with Article 44-1 of the Inspection, Article 46-1 Settlement in cases of anticompetitive concerted actions and abuse of monopoly (dominant) position, as well as the introduction of joint and several liability for payment bodies of the Fine Committee.

Key words: reforming the system of legal regulation, protection of economic competition, antitrust regulation, leniency program, joint and several liability. 